\title{
Peptide hydrolase activity of human intestinal mucosa in adult coeliac disease
}

\author{
ADRIAN P. DOUGLAS AND T. J. PETERS \\ From the MRC Intestinal Malabsorption Group and Department of Medicine, Royal Postgraduate \\ Medical School, London
}

SUMMARY The levels of two peptide hydrolases were studied in intestinal mucosa from normal subjects, patients with untreated coeliac disease, and treated patients. The mucosa from the untreated patients had significantly reduced activity against glycyl-glycine and leucylleucine. No such difference was found for the treated patients and it was concluded that the reduction in peptidase activity was secondary to the mucosal damage.

It has been suggested that coeliac disease is due to the absence from the intestinal mucosa of a peptide hydrolase, which normally plays an important role in the digestion of gluten (Frazer, 1956). Such a hypothesis would explain the fact that the toxic properties of the peptides obtained by peptic-tryptic digestion are removed by further digestion with porcine intestinal mucosa (Frazer, Fletcher, Ross, Shaw, Sammons, and Schneider, 1959). Investigation of this hypothesis has been hampered by lack of knowledge of the exact nature of the toxic peptide or peptides, but recent evidence from studies using digests of gluten suggests that there is no primary deficiency of those intestinal peptide hydrolases concerned with gluten digestion in coeliac disease (Douglas and Booth, 1959).

We report here estimations of two peptide hydrolases, glycyl-glycine dipeptidase (EC 3.4.3.1) and leucyl-leucine dipeptidase (EC 3.4.1.1) in human intestinal mucosa from normal control subjects and from patients with untreated and with treated adult coeliac disease. Our results show that there is a decrease in peptide hydrolase activity in untreated coeliac disease. However, after treatment either by withdrawing gluten or with corticosteroids this activity returns to normal. This finding further supports the suggestion that the decrease in peptide hydrolase activity in untreated coeliac disease is secondary to mucosal damage.

\section{Materials and Methods}

\section{JEJUNAL MUCOSA}

This was obtained with a Crosby capsule located under fluoroscopic control beyond the ligament of Treitz. A portion of the specimen was processed for histological examination and the remainder snap frozen in liquid nitrogen and stored at $-25^{\circ}$ until assayed.

\section{SUBJECTS STUDIED}

Thirty-one intestinal biopsies from 27 subjects with adult coeliac disease were studied. The diagnosis in each case was based on the presence of malabsorption of at least two nutrients, a low serum folate level and a typical appearance of the jejunal mucosa on biopsy. Thirteen of the biopsies were from patients who were untreated at the time of study. Ten biopsies were from patients who had been treated with a gluten-free diet for a period of three months to five years. Eight biopsies were from patients who had been treated with oral prednisolone, $40 \mathrm{mg} /$ day for 21 to 35 
days. (This group is reported in greater detail elsewhere by Wall, Douglas, Booth, and Pearse, 1969.) Of the 18 biopsies from patients with treated coeliac disease, three were normal by histological criteria, and the remainder, although not showing villi, had normal surface epithelial cells. For comparison biopsies from 15 control subjects without evidence of malabsorptive disease were also studied. These biopsies were normal on histological examination.

\section{ASSAY PROCEDURE}

The intestinal mucosa was weighed and homogenized in ice-cold distilled water. A concentration of 25 to $50 \mathrm{mg}$ wet weight $/ \mathrm{ml}$ was used. The protein content of the homogenates were estimated by the method of Lowry, Rosebrough, Farr, and Randell (1951) using bovine serum albumin (Armour) as standard. The peptide hydrolases were assayed using the kinetic system described by Lenard, Johnson, Hyman, and Hess (1965). The use of this system for the assay of guinea-pig intestinal peptide hydrolase has already been described (Peters, 1969). One unit of activity corresponds to the hydrolysis of $1 \mu$ mole of peptide per hour under the conditions used.

\begin{tabular}{lcc}
\hline Peptide & $\mathrm{pH}$ Optimum & Metal Activator \\
\hline Glycyl-glycine & $7 \cdot 4$ & $0.25 \mathrm{mM} \mathrm{Co}^{2+}$ \\
L Leucyl-L leucine & $8 \cdot 0$ & $0.25 \mathrm{mM} \mathrm{Mn}^{2+}$ \\
'Temperature $37^{\circ} \mathrm{C} ;$ Buffer, M/15 & phosphate (Sörensen, 1909); \\
substitute concentration, $0.2 \mathrm{mM}$. &
\end{tabular}

Table I Conditions used for glycyl-glycine and L leucyl-L leucine peptide hydrolase assay ${ }^{1}$
Both peptide hydrolases were assayed at the optimum $p \mathrm{H}$ using the appropriate metal ion as activator. Table I shows details of the assay conditions used.

\section{Results}

The activities for glycyl-glycine peptide hydrolase are shown in Fig. 1 and for leucyl-leucine in Figure 2. For both enzymes there is a highly significant decrease in specific activity in the untreated patients compared with that in the normal controls. There is not, however, any significant difference between the normal group and the treated groups for either of the peptide hydrolases. Both the patients treated by gluten withdrawal and those treated with prednisolone showed a similar rise in their intestinal peptide hydrolase levels. In two patients serial biopsies were obtained before and during successful treatment with oral prednisolone. In the four patients in whom results of peptide hydrolase activity were available both before and after successful treatment hydrolase activity increased concurrently with treatment (Table II).

\begin{tabular}{llll}
\hline $\begin{array}{l}\text { Case } \\
\text { No. }\end{array}$ & Peptide & $\begin{array}{l}\text { Untreated } \\
\text { (units/mg protein) }\end{array}$ & $\begin{array}{c}\text { Treated } \\
\text { (units } / \text { mg protein) }\end{array}$ \\
\hline 54 & Glycyl-glycine & $0 \cdot 14$ & $0 \cdot 70$ \\
56 & & $0 \cdot 52$ & $1 \cdot 56$ \\
113 & L leucyl-L leucine & $1 \cdot 28$ & $12 \cdot 1$ \\
117 & & $4 \cdot 16$ & $9 \cdot 40$
\end{tabular}

Table II Effect of treatment of adult coeliac disease on the peptide hydrolase activity of the jejunal mucosa

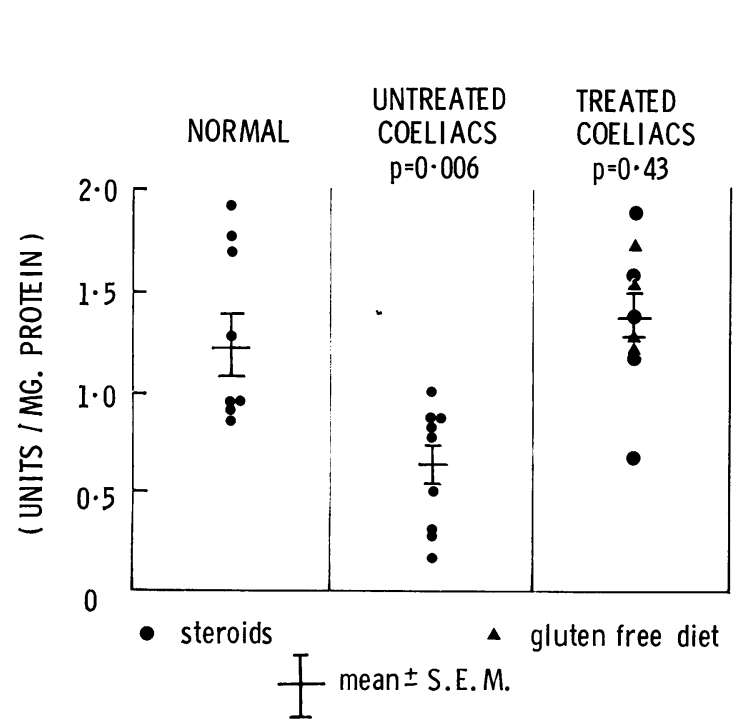

Fig. 1 Glycyl-glycine peptide hydrolase activity in the jejunal mucosa from normal control subjects and patients with untreated and treated adult coeliac disease.
Fig. 2 L leucyl-L leucine peptide hydrolase activity in the jejunal mucosa from normal control subjects and patients with untreated and treated adult coeliac disease. 


\section{Discussion}

The observation that the peptide hydrolase activity is normal in mucosa from patients with treated coeliac disease must mean that, at least for the two hydrolases studied, there is no primary enzyme deficiency. It is noteworthy that apparently normal levels of peptide hydrolase activity were found in treated patients although the mucosa has not returned to histological normality.

Previous workers have studied the ability of jejunal mucosa to hydrolyse several different peptides (Messer, Anderson, and Townley, 1961; Crabbe, 1964; Pittman and Pollitt, 1966; Lindberg, Nordén, and Josefsson, 1968; Douglas and Booth, 1969), but this is the first study using a continuous kinetic assay system. This may be important, as it is possible that hydrolytic rates may be reduced in coeliac disease without any gross reduction in total activity. Two previous studies (Messer et al, 1961; Lindberg et al, 1968) have shown low peptide hydrolase levels in untreated coeliac disease compared with that in normal controls but this is the first systematic study of peptide hydrolase levels in both untreated and treated cases. This study also emphasized the importance of using treated coeliac patients in a search for the deficient peptide hydrolase, postulated by Frazer (1956). The observation that steroid therapy led to an increase in peptide hydrolase activity even though gluten was not withdrawn from the diet is further evidence against a primary enzyme deficiency. Thus it is probable that the reduced level of peptide hydrolase observed in the intestinal mucosa of adult coeliac disease is not a primary phenomenon. Similar conclusions for alkaline phosphatase and several disaccharidases have reached by other workers (Plotkin and Isselbacher, 1964; Weser and Sleisenger, 1965).

We are grateful to Professor C. C. Booth for allowing us to study his patients and for continual encouragement, and to the Technicon Instrument Co. for the loan of equipment.

Both authors are MRC clinical research fellows.
Lenard, J., Johnson, S. L., Hyman, R. W., and Hess, G. P. (1965). A continuous automatic method for the study of rate of hydrolysis of peptides and amides. Analyt. Biochem., 11, $30-41$.

Lindberg, T., Nordén, A., and Josefsson, L. (1968). Intestinal dipeptidases. Dipeptidase activities in small intestinal biopsy specimens from a clinical material. Scand. $J$. Gastroent., 3, 177-182.

Lowry, O. H., Rosebrough, N. J., Farr, A. L., and Randell, R. J. (1951). Protein measurement with the Folin phenol reagent. J. biol. Chem., 193, 265-275.

Messer, M., Anderson, C. M., and Townley, R. R. W. (1961). Peptidase activity of biopsies of the duodenal mucosa of children with and without coeliac disease. Clin. chim. Acta, 6, 768-775.

Peters, T. J. (1969). Application of an improved kinetic assay system to the study of the sub-cellular localisation of peptidases. J. Physiol. (Lond.). 202, 13p.

Pittman, F. E., and Pollitt, R. J. (1966). Studies of jejunal mucosal digestion of peptic-tryptic digests of wheat protein in coeliac disease. Gut, 7, 368-371.

Plotkin, G. R., and Isselbachər, K. J. (1964). Secondary disaccharidase deficiency in adult celiac disease (non-tropical sprue) and other malabsorption states. New Engl. J. Med., 271, 1033-1037.

Sörensen, S. P. L. (1909). Ergänzung zu der Abhandlung: Enzymstudien II: Uber die Messung und die Bedeutung der Wasserstoffionenkonzentration bei enzymatischen Prozessen. Biochem. Z., 22, 352-356.

Wall, A. J., Douglas, A. P., Booth, C. C., and Pearse, A. G. E. (1969). The response of the jejunal mucosa in adult coeliac disease to oral prednisolone. (In preparation.)

Weser, E., and Sleisenger, M. H. (1965). Lactosuria and lactase deficiency in adult celiac disease. Gastroenterology, 48, 571-578.
References

Crabbe, P. (1964). Sprue non tropicale: étiologie et pathogénie. Acta gastroent. belg., 27, 7-18.

Douglas, A. P., and Booth, C. C. (1969). Digestion of gluten peptides by normal human jejunal mucosa and by mucosa from patients with adult coeliac disease. (Submitted for publication.)

Frazer, A. C. (1956). Discussion on some problems of steatorrhoea and reduced stature. Proc. roy. Soc. Med., 49, 1009-1013.

Frazer, A. C., Fletcher, R. F., Ross, C. A. C., Shaw, B., Sammons, H. G., and Schneider, R. (1959). Gluten induced enteropathy: the effect of partially digested gluten. Lancet, 2 , 252-255. 